Review Article

\title{
COVID-19, ARDS, ACOVCS, MIS-C, KD, PMIS, TSS, MIS-A: Connecting the Alphabet?
}

\section{Patrick William Chambers}

Department of Pathology, Torrance Memorial Medical Center, USA

\section{Abstract}

Covid-19 has presented the world with a multitude of different clinical faces. To date their linkage eludes. This article attempts to establish linkage using recent research results regarding blood groups, clinical findings, cytokines, epidemiology, and the CD147 receptor, the orphan sister of ACE2. The role of the immune system controlled by the RAS and vitamin D is explored and recommendations ventured.

Keywords: COVID-19; SARS; Cardiovascular syndrome; ARDS

\section{Introduction}

From the first quarter of 2020 thru its third quarter COVID-19 has ranged clinically from a flu-like illness to Acute Respiratory Distress Syndrome (ARDS) with co-morbidities to Acute Covid Cardiovascular Syndrome (ACovCS) with or without co-morbidities to Multi system Inflammatory Syndrome in Children (MIS-C) aka Pediatric Multi system Inflammatory Syndrome-Toxic Shock Syndrome (PMIS-TSS in UK) and back to adults with MIS-A, both without significant respiratory illness.

Is there a link connecting these seemingly disparate clinical presentations?

SARS CoV2 (SARS2) has been compared to SARS CoV (SARS1), its closest human viral pathogen. But there are numerous seemingly inexplicable clinical differences, despite the shared ACE2 receptor preference for their spike protein attachment. Questions include:

Why are the ABO blood groups preferred by SARS1 different from those preferred by SARS2?

Why is obesity such a prominent risk factor for SARS2 versus protective for SARS1?

How can SARS2 cross the blood brain barrier but SARS1 cannot?

Are anosmia and ageusia a reflection of this capacity?

Why does SARS2 cause frequent severe Thrombotic Microangiopathy (TMA) but SARS1 did not?

Why is there some reported efficacy with hydroxychloroquine for SARS2 but not for SARS1?

Citation: Patrick William Chambers. COVID-19, ARDS, ACOVCS, MIS-C, KD, PMIS, TSS, MIS-A: Connecting the Alphabet?. Clin Med. 2020; 2(2): 1027.

Copyright: ๑ 2020 Patrick William Chambers

Publisher Name: Medtext Publications LLC

Manuscript compiled: Dec $14^{\text {th }}, 2020$

*Corresponding author: Patrick William Chambers, Department of Pathology, Torrance Memorial Medical Center, 3330 Lomita Blvd, Torrance, CA 90505, USA, Tel: 8087783236; E-mail: pwc@gte.net

\section{SARS1 v SARS2 and CD147}

SARS1 Nucleocapsid protein (N) may bind to CD147 receptors but unlike SARS2, its Spike protein (S) cannot bind to CD147 receptors. TMPRSS2 cleaves the spike protein enabling membrane fusion and cellular entry of both SARS1 and SARS2 via ACE2 receptors. TMPRSS2 cannot cleave the nucleocapsid protein $[1,2]$. In March 2020 Wang et al. [3] reported that SARS2 could also enter cells via the CD 147 receptor.

While there is some controversy regarding binding of SARS2 spike protein to CD147 receptors, it appears more likely than not.

\section{ACE2 v CD147}

Initially the ACE2 receptor was shown to be the entry point for SARS2. There was a great deal of controversy about whether having more ACE2 receptors was good or bad. ACE2 receptors have long been known to mitigate the severity of any viral respiratory illness, but RAS antagonists, which up-regulate ACE2 receptors [4], were quickly cast as villains.

Then CD147 aka EMMPRIN (Extracellular Matrix Metalloproteinase Inducer) aka basigin aka neurothelin was suggested as a point of entry for SARS2 [3]. This is the same receptor that Plasmodium falciparum, the most lethal species of the malarial parasite, uses to invade erythrocytes. It is also found on all immune cells, endothelial cells, and epithelial cells. ACE2 receptors are less abundant, less widespread and appear to be limited to barrier cells, bronchial cells and skin. Their presence on endothelial cells is controversial. Perhaps the presence of CD147 receptors on endothelial cells is more significant $[5,6]$.

ACE2 and CD147 expression is cell and organ specific. For example CD147 is highly expressed in immune cells of children, whereas its expression is lower in adolescents and in adults. CD147related genes in the bronchial cells on the other hand increase with age [7].

The decreasing expression of CD147 on immune cells might explain why the proportion of severe and critical cases of MIS-C are highest after birth and decline through puberty [8]. The low expression of CD147 on bronchial cells during childhood might explain the lack of significant pediatric respiratory illness? 
"We did not see any major differences in the gene expression (ACE2 or CD147) in the bronchial biopsies based on hypertension, smoking, gender, and obesity, except higher ACE2 expression in smokers". This might explain the smokers paradox with SARS2.

On the other hand, asthma, COPD, hypertension, obesity, and male gender status generally led to higher expression of CD147-related genes in the blood. Additionally, CD147-related genes correlated positively with age and BMI in Peripheral Blood Mononuclear Cells (PBMCs). Diabetes was also implicated in this correlation in blood, i.e., in immune cells, which have CD147 but not ACE2 receptors [7].

So, perhaps it might be instructive to compare specific aspects of SARS2 (ACE2 and CD147) with those of malaria (CD147) and those of SARS1 (ACE2).

\section{ABO Preferences}

SARS1 was most severe in blood types $\mathrm{A}>\mathrm{AB}>\mathrm{B}, \mathrm{O}$

Anti-A in B and O blood types protected against SARS1 by inhibiting entry via ACE2 receptors [9]. [10].

P. falciparum malaria is most severe in blood types $\mathrm{B}>\mathrm{A}, \mathrm{AB}>\mathrm{O}$

Low Von Willebrand Factor (vWF) protects against thrombosis. Elevated vWF predisposes to thrombosis.

The level of vWF differed significantly between blood groups. In individuals with blood-group O, the mean vWF level was $1.29 \mathrm{kIU} / \mathrm{l}$, blood group A $1.52 \mathrm{kIU} / \mathrm{l}$, blood group AB $1.59 \mathrm{kIU} / \mathrm{l}$, and blood group B $1.76 \mathrm{kIU} / \mathrm{l}$ [11].

SARS2 is most severe in blood types $\mathrm{A}>\mathrm{B}, \mathrm{AB}>\mathrm{O}$ [12].

Decreased vWF in the O group (30\% less thrombosis) is thought to be the protective mechanism (less Disseminated Intravascular Coagulation (DIC)) in SARS2 and malaria. B blood type has the highest levels of vWF and therefore should be the most susceptible to SARS2 and DIC. But A's are reported to be most susceptible to SARS2, presumably because they do not have anti-As.

If anti A provided significant protection, as in SARS1, then B susceptibility to SARS2 should equal that for O.

If low vWF activity provided significant protection, as in malaria then B susceptibility to SARS2 should be greater than that for A.

Perhaps this preference of SARS2 for blood group $A>B / A B>O$ represents a mix of SARS1 (ACE2) and malarial (CD147) preferences.

\section{Thrombotic Microangiopathy (TMA)}

SARS1 elicited D-dimers and thrombosis but not severe TMA aka Thrombotic Thrombocytopenic Purpura (TTP) aka atypical hemolytic uremic syndrome [13].

SARS2 elicits severe thrombotic microangiopathy with D-dimers and thrombocytopenia early poor prognosticators. Increased RDW (Red cell Distribution Width) might also be an early indicator [14].

Perhaps CD147 receptors on the surface of erythrocytes soak up SARS2 virions. RDW increases and erythrocytes are entrapped in the spleen, which enlarges $[15,16]$.

\section{Clinical Findings}

SARS1 exhibited flu-like symptoms in children and adults; extra pulmonary spread was primarily renal but not CNS.
SARS2 exhibits flu-like symptoms in adults (but rarely children), exhibits more significant extra pulmonary spread (including CNS thru the Blood Brain Barrier (BBB)), and exhibits susceptibility to hydroxychloroquine in some reports [17].

But hydroxychloroquine is useful for treatment of vasculitis, which appears to be at the heart of Covid-19 [18].

Anosmia may be the first sign of neuro-invasion likely due to CD147, not ACE2. It was an insignificant symptom in SARS1 [19-21].

Malaria can spread to the CNS, cross the BBB, and is often treated with hydroxychloroquine [22].

\section{The Obesity Paradox}

Obesity was protective with SARS1 but is highly problematic with malaria and SARS2 $[23,24]$.

CD147 expression in immune cells, which do not express ACE2, is directly proportional to BMI and age [7].

\section{Cytokines}

SARS1 cytokines include MCP-1, TGF- $\beta 1$, TNF- $\alpha$, IL- 6 , IFN- $\gamma$, IL-1 $\beta$, IL-2, and IL-5 [25].

Significant SARS2 cytokines include IL-1 $\beta$, IL-6, IL-8, IL-10, TNF- $\alpha$, INF- $\gamma[26]$.

Malaria elicits IL-1 $\beta$, IL-6, IL-8, IL-10, TNF- $\alpha$, and IL-12 [27].

The cytokines of SARS2, especially those most indicative of severity, IL-6,8,10, TNF- $\alpha$ appear to be slightly more akin to falciparum malaria than to SARS1.

IL-10, a strong anti-inflammatory cytokine produced by T2 helper cells (Th2), is oddly elevated in SARS2 and cerebral malaria. It appears that Th1 cells (pro inflammatory) can also produce IL-10 to dampen inflammation in the face of intractable infection $[28,29]$.

\section{Epidemiology}

TNF- $\alpha$ and IL-10 discriminate between patients with MIS-C and severe Covid-19 [30].

These are the same markers that differentiate severe Covid-19 from that less severe [31,32].

Significant respiratory illness is not common in MIS-C (25\% obese, $10 \%$ asthma), yet the levels of cytokines indicating severity are higher than even those in severe Covid-19. This is despite the absence of co-morbidities. ARDS can rarely be seen in the pediatric group but not without co-morbidities [30]. What might trigger an even greater Th1/Th2 cytokine imbalance than that seen in severe Covid-19 (1/2 obese, $1 / 2$ hypertensive, $1 / 3$ diabetic)? One can speculate that vitamin D deficiency might play a vital role. The ethnic preferences for SARS2 offer some support for this speculation.

Approximately $75 \%$ of those diagnosed, hospitalized, or admitted to the ICU with Covid-19 or are black or Hispanic. Over $90 \%$ of those with MIS-A are black or Hispanic [33]. Are those with MIS-A severely vitamin D deficient?

By comparing blood type preferences, cytokine profiles, BMI discrepancies, severe TMA frequency, and clinical findings in SARS1, SARS2, and malaria, a distinct hybrid profile for SARS2 begins to emerge. The epidemiology of Covid-19 points to a prominent role for vitamin D deficiency and possible benefits of RAS antagonism. Not only is the Th1 arm up-regulated but also the Th2 arm is down 
regulated with low vitamin D [34]. Vitamin D deficiency has been reported in KD [35], Covid-19 [36] and MIS-C [36] (Figure 1).

There have been modest increases in whites [37] (Figure 2). But NHANES data underscores the predilection for low 25(OH)D in the black/Hispanic population with continuing deterioration. The trend is toward lower levels of $25(\mathrm{OH}) \mathrm{D}$ by age, sex, and ethnicity. Might ACovCS and MIS-A also reflects a poor vitamin D status? (Figure 3).

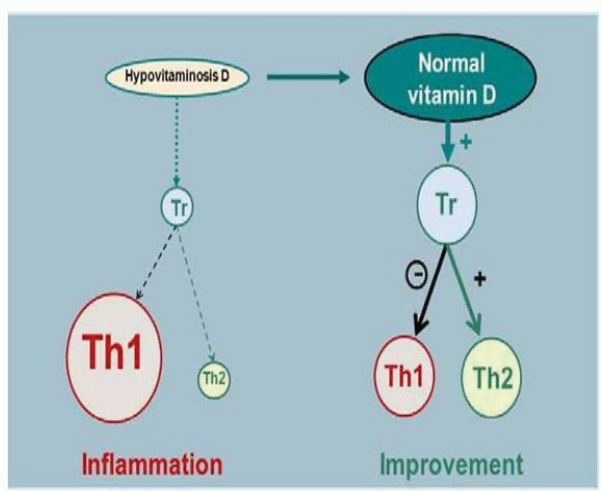

Figure 1: Vitamin D connection.

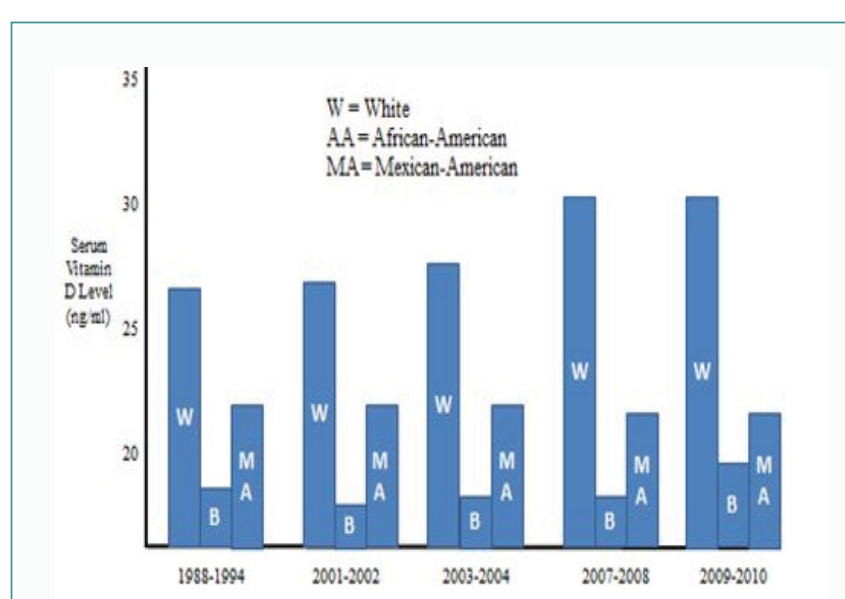

Figure 2: Vitamin D status of 3 U.S. ethnic groups: 1988 through 2010.

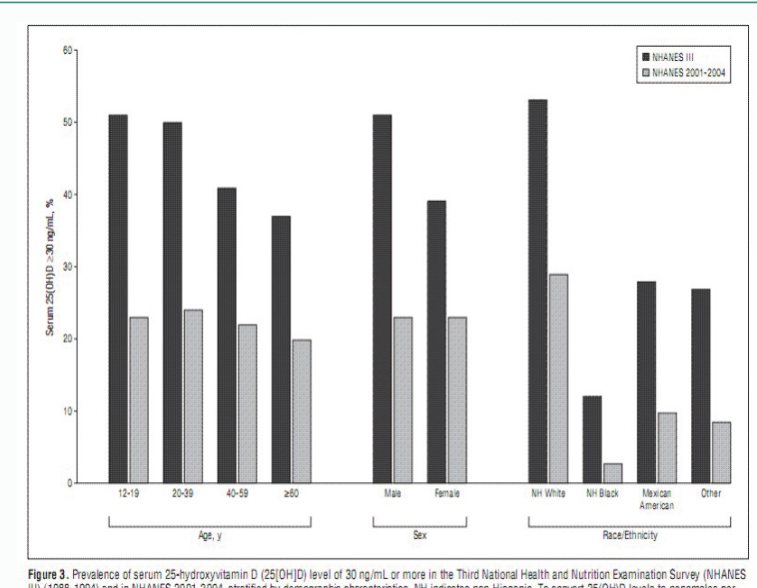

Figure 3: Prevalence of serum 25-hydroxyvitamin $\mathrm{D}(25[\mathrm{OH}] \mathrm{D})$ level of $30 \mathrm{ng} / \mathrm{mL}$ or more in the Third National Health and Nutrition Examination Survery (NHANESIII) (1988-1994) and in NHANES 2001-2004, stratified by demogarphic characteristics. $\mathrm{NH}$ indicates non-Hispanic. To convert 25[OH] $\mathrm{D}$ levels to nanomoles per liter, multiply by 2.496 .

\section{RAS Connection}

Numerous reports implicate TNF- $\alpha$ in the pathogenesis of Kawasaki's Disease (KD) [38,39], Toxic Shock Syndrome (TSS) [40], Covid-19 [41], MIS-C [41], and malaria [42]. These entities also seem to be linked by vasculitis, especially coronary vasculitis.

TNF- $\alpha$ is produced by TACE (Tumor necrosis factor a Converting Enzyme), also known as ADAM17 (A Disintegrin and Metalloproteinase \#17). ADAMA17 is activated by AT1Rs, the primary receptor for angiotensin II. It cleaves ACE2 and IL-6 receptors, increasing their plasma counterparts, which are poor prognosticators. TACE (and angiotensin II) are integral to the proinflammatory $\mathrm{v}$ anti-inflammatory balance.

Angiotensin II antagonists impact SARS CoV2 entry. ADAM17 enables endocytosis and internalization of the virus. The AT1R chaperones the viral ACE2 complex to the lysosome, but the virus fuses with the endosome membrane and escapes into the cytoplasm [43]. ADAM17 also cleaves membrane ACE2. Both processes require AT1Rs. Circulating or soluble ACE2 is a poor prognosticator [44,45] (Figure 4). Circulating or soluble IL-10 is a poor prognosticator [46,47] (Figure 5).

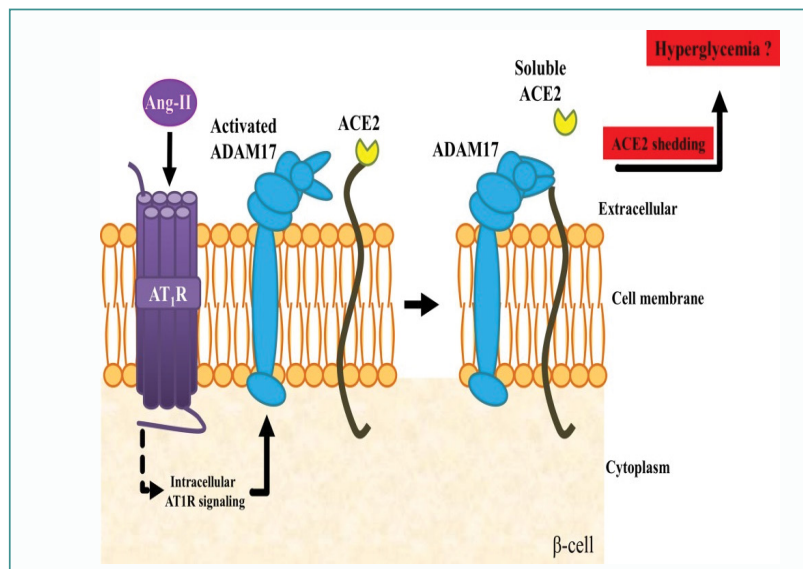

Figure 4: Tumor necrosis factor Alpha Converting Enzyme (TACE) aka ADAM17 cleaves ACE2 (creating soluble or circulating ACE2, a bad prognosticator) in addition to producing the cytokine TNF alpha, an indicator of Covid-19 severity.

\section{Pro- and Anti-Inflammatory Activities of Interleukin-6}

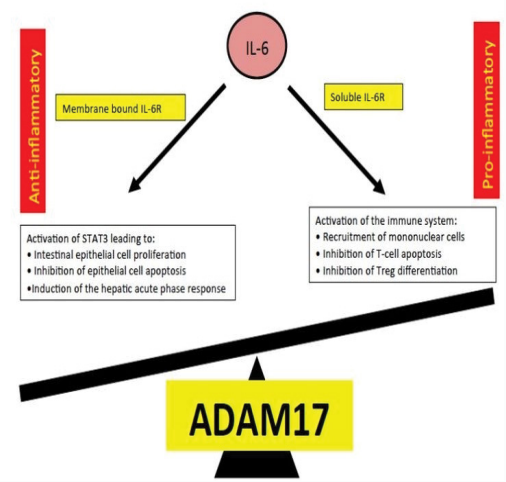

Figure 5: TACE also produces the cytokine IL-6 (a bad prognosticator) in the same manner. 
Vitamin D inhibits renin, a precursor to angiotensin II, and counterbalances ADAM17 by down regulating the pro-inflammatory cytokines and up regulating the anti-inflammatory ones. Vitamin D also inhibits NF- $\mathrm{KB}$ and works against the RAS from above and below [48] (Figure 6). NF- $\kappa B$ is a prominent player in the pro inflammatory response [49] (Figure 7). Vitamin D immunomodulates both innate and adaptive immunity (Figure 8 ).
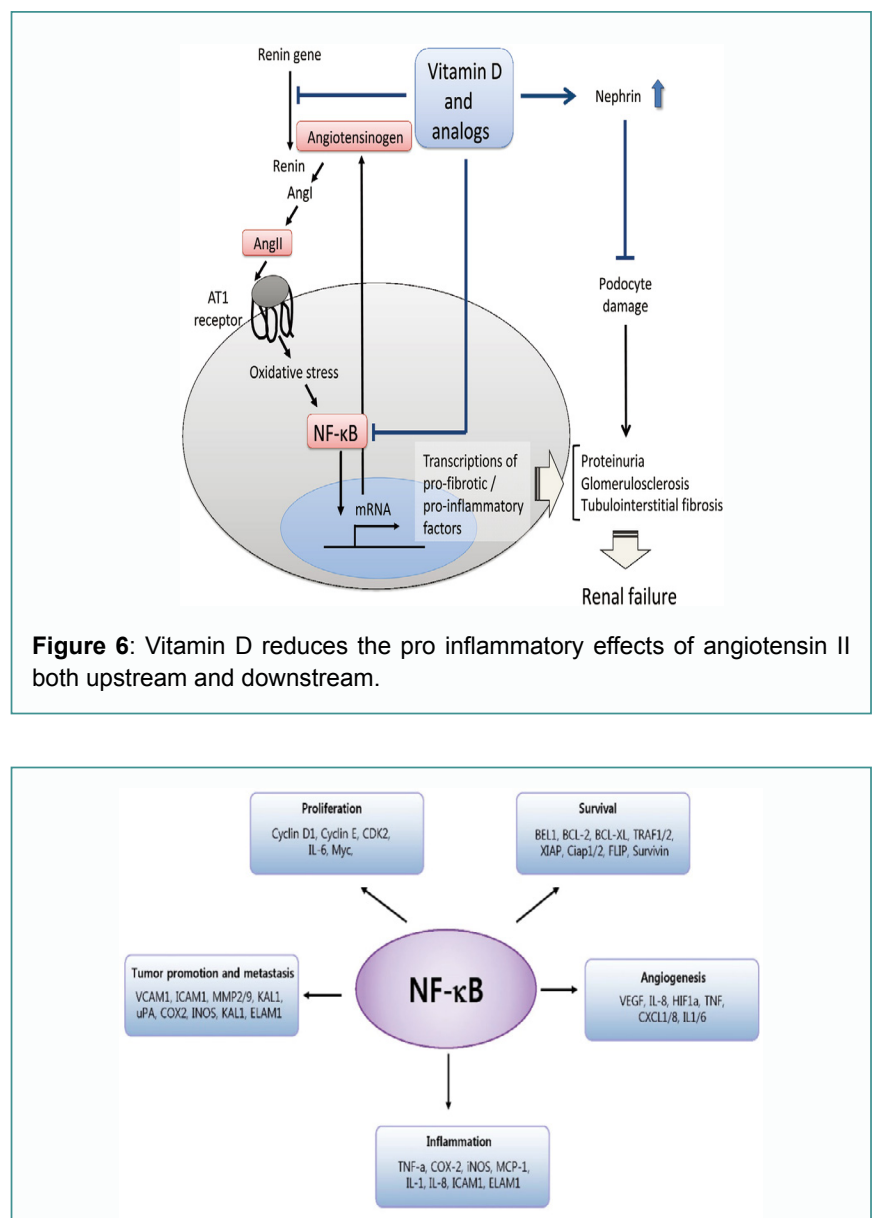

Figure 7: The pro inflammatory effects of NF-kappaB are myriad.

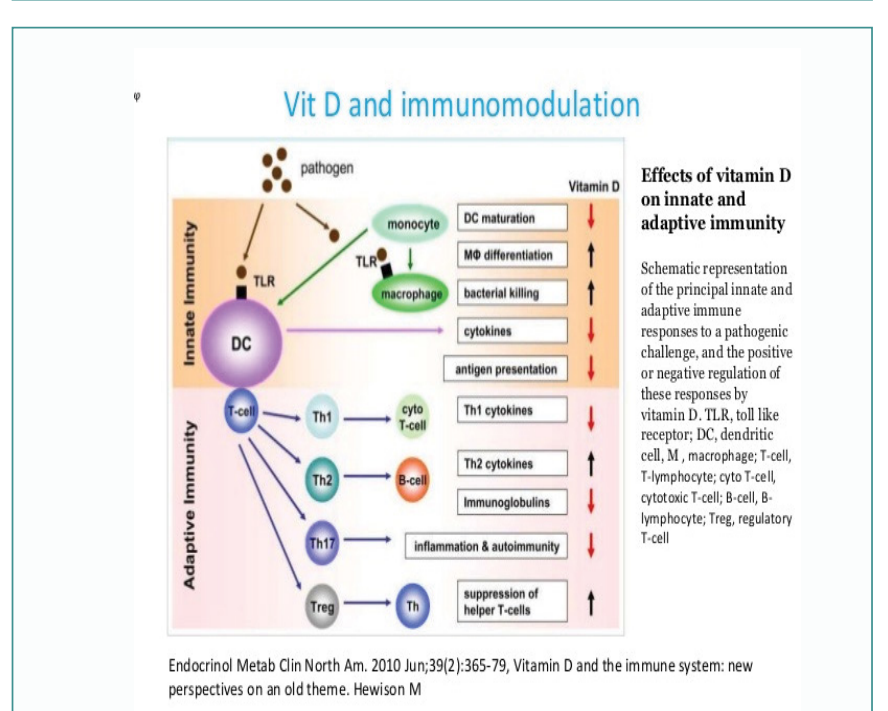

Figure 8: Th1, Th17 are pro inflammatory and Th2, Treg are anti-inflammatory.

\section{Discussion}

SARS1 and SARS2 differ in the immune response they elicit [50].

SARS1 and especially SARS2 retard the innate immune response (INF- $\alpha$ and $\beta$ which are type I interferons) thru production of ORFs (Open Reading Frames) and NSPS (Non-Structural Proteins) [51].

This conforms nicely to the cytokine/viral load data seen in SARS1 (more cytokines) v SARS2 (higher viral load) [50] (Figure 9).

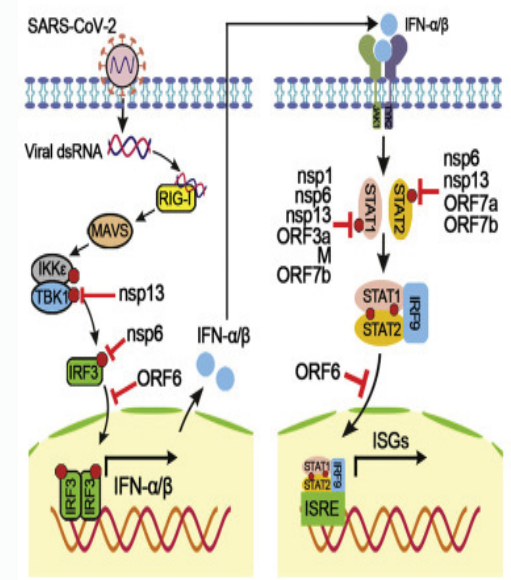

Figure 9: IFN alpha and beta are innate immunity cytokines which are inhibited by SARS2.

SARS2 effectively bypasses innate immunity and enters adaptive immunity unscathed. It eclipses SARS1 not only in suppression of this innate immune response but alsospike protein (S) binding affinity. In destroying ACE2 receptor positive cells SARS2 infection increases angiotensin II, which is linearly associated with viral load and lung injury [52].

Around the time of the activation of adaptive immunity Covid-19 patients often become critically ill. A hyper-inflammatory response by human macrophages breaks pulmonary endothelial barrier integrity and induces microvascular thrombosis [53].

Whether this is mediated by ACE2 receptor or CD147 receptor positive cells or both is not clear. The increase in angiotensin II suggests the former may be more contributory. ACE/ACE2 is increased in hypertension and diabetes, both risk factors for SARS2. Diabetes and obesity are also risk factors for malaria (CD147) $[54,55]$.

Whether ACE2 receptors are present in adipose tissue appears controversial [56].

However, the mortality rate of SARS1 in the obese was lower not higher, despite using the same ACE2 receptor. Furthermore, melatonin via CD147 receptors has been found effective in treating Covid-19 [57-59]. Brown fat is rich in CD147 receptors. So, it appears more likely that CD147 receptors are responsible for Covid-19 risk in the obese.

TMPRSS2 is the required protease that enables viral entry once its $S$ protein is attached to the ACE2 receptor. TMPRSS2 may also facilitate viral entry once its S protein is attached to a CD147 receptor [60].

Cyclophilins A and B may also possibly function in this manner [7]. 
If the Covid-19 patient has no comorbidities and ACE/ACE2 are in balance, the only symptom may be flu-like (ACE2) with or without anosmia/ageusia (CD147). ACE2 receptors function like fixed antibodies, soaking up the virus and, depending on the inoculum dosage, possibly thwarting the attack.

If ACE/ACE2 is already out of balance, e.g., hypertension, diabetes, then ACE2 receptors may be easily overwhelmed concomitant with additional increases in angiotensin II.

This disturbs the balance between angiotensin II and the probable pre-existing shortfall of vitamin D [61] (Figure 10). These same comorbidities (diabetes and hypertension), obesity, and male gender upregulate CD147 receptors present ubiquitously in epithelial, endothelial, and immune cells [7].

Once the comorbid patient enters the adaptive immunity phase ARDS might develop. If additionally a significant vitamin D deficiency exists, the illness can become autoimmune-like, possibly via CD147 receptors [62].

So, angiotensin II and vitamin D jointly determine not only the magnitude of the innate and adaptive immune response but also the balance between pro-inflammatory and anti-inflammatory.

If active $D$ is sufficient ( $40 \mathrm{ng} / \mathrm{ml}$ to $60 \mathrm{ng} / \mathrm{ml}$ ), Th1,17 and Th2,Treg are balanced and SARS2 can be contained. If deficient, then Th1,Th17>Th2,Treg and TMA can develop in addition to ARDS. If deficient with or without comorbidities, CD147 receptors on endothelial cells can cause an autoimmune-like vasculitis. The virus spreads to the heart (ACovCS with or without comorbidities) and beyond, crossing the blood brain barrier. At this point Covid-19 behavior becomes more malaria-like with D-dimers, thrombocytopenia, and TMA.

If sufficiently severe, vitamin $\mathrm{D}$ deficiency might explain the autoimmune symptomatology of MIS-C and MIS-A. Ethnic epidemiology supports this view. MIS-C, PMIS-TSS, TSS, KD exhibit similar symptoms. TNF- $\alpha$ is elevated in all. TNF- $\alpha$ is a lymphotoxin that can cause fever, vasculitis, lymphadenopathy, skin rash,..

Low levels of $25(\mathrm{OH}) \mathrm{D}$ in childhood support the reports of vitamin D deficiency in both KD and MIS-C. Kawasaki's Disease peaks at 4 years of age. MIS-C incidence peaks at eight years of age [63].

This older peak in MIS-C might reflect the net effect from birth of decreasing AT2Rs with increasing ACE2s. Before 8 years of age the net effect is increasing susceptibility. After 8 years of age the net effect is decreasing susceptibility. At this point the increasing ACE2s may overcome the decreasing AT2Rs for a net deterrent to Covid-19 infection [64,65] (Figure 11).

According to the CDC, MIS-C and MIS-A are described as entities following by about four weeks a previous Covid-19 infection [30,33] (Figure 12).

The vitamin $\mathrm{D}$ deficiency translates to not only a significant increase in the Th1/17 pathway (cellular immunity) but also a significant decrease in the Th2 pathway (humoral immunity) and an antibody shortfall. This might explain the weak/slow initial antibody response and the Antibody Dependent Enhancement (ADE) like autoimmune-like recurrence in MIS-C and MIS-A (Figure 13).

One study of asymptomatic Covid-19 patients demonstrated a geometric mean neutralizing antibody titer of 1:78 at eight weeks post infection [66].

One study on ADE in dengue fever indicated a neutralizing titer between 1:21 and 1:80 enhanced the risk of reinfection almost eightfold $[67,68]$.

MIS-C and MIS-A might represent secondary exposures mediated by ADE and severe vitamin D deficiency (Figure 14). The official recommendations for vitamin D sufficiency are grossly short of the proper target.

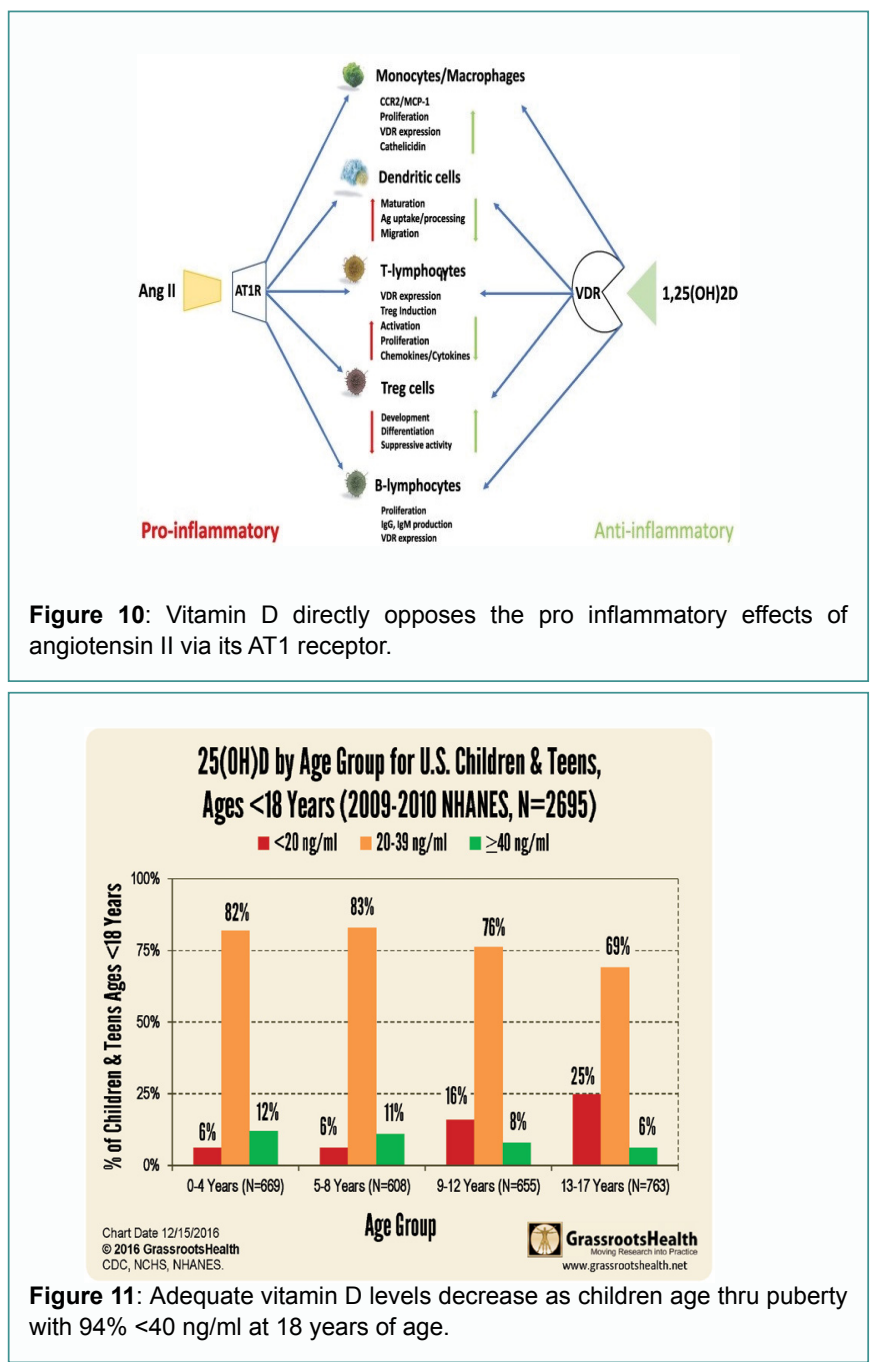

Vitamin D deficiency/insufficiency depends on cutoff [69] (Figure 15).

The calculations by the National Academy of Sciences Institute of Medicine (IOM) that determined their Recommended Dietary Allowance (RDA) of 600 IUs to 800 IUs per day in 2014 was off by an order of magnitude. This huge error was confirmed by several Canadian and American university research teams [70].

The IOM's RDA for vitamin D still stands at 600 IUs to 800 IUs, but their Estimated Average Requirement (EAR) was raised from 20 $\mathrm{ng} / \mathrm{ml}$ to $30 \mathrm{mg} / \mathrm{ml}$.

Many physicians and other organizations recommend arange of $50 \mathrm{ng} / \mathrm{ml}$ to $70 \mathrm{ng} / \mathrm{ml}[71]$.

Is there objective evidence to support such target recommendations? [72] (Figure 16). 


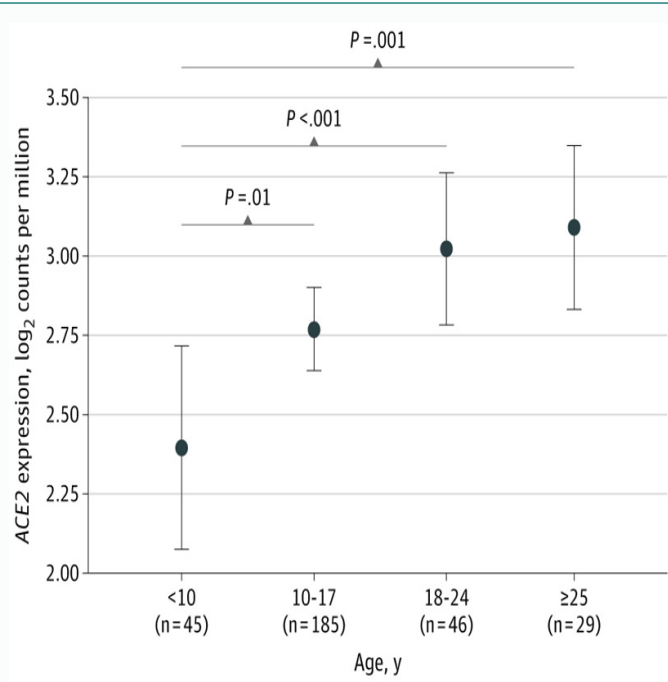

Figure 12: ACE2 receptors are low at birth and increase with age, plateauing after 25 years of age.

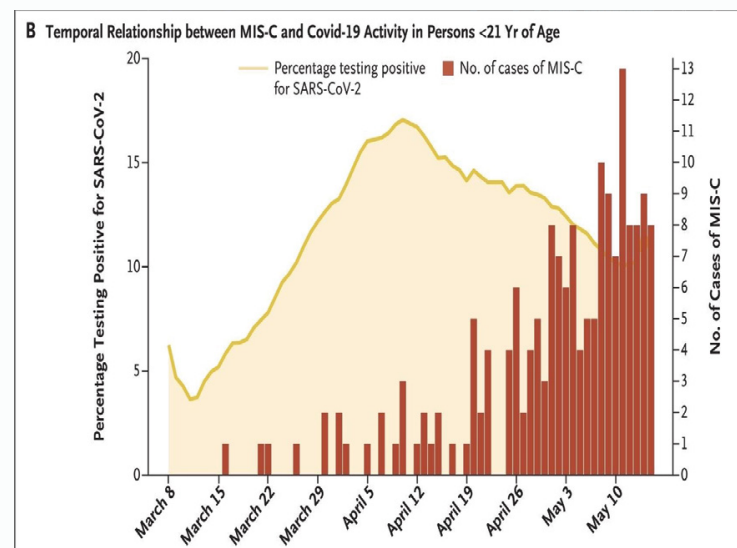

Figure 13: According to the CDC, MIS-C cases peaked about four weeks after the peak in cases of Covid-19.

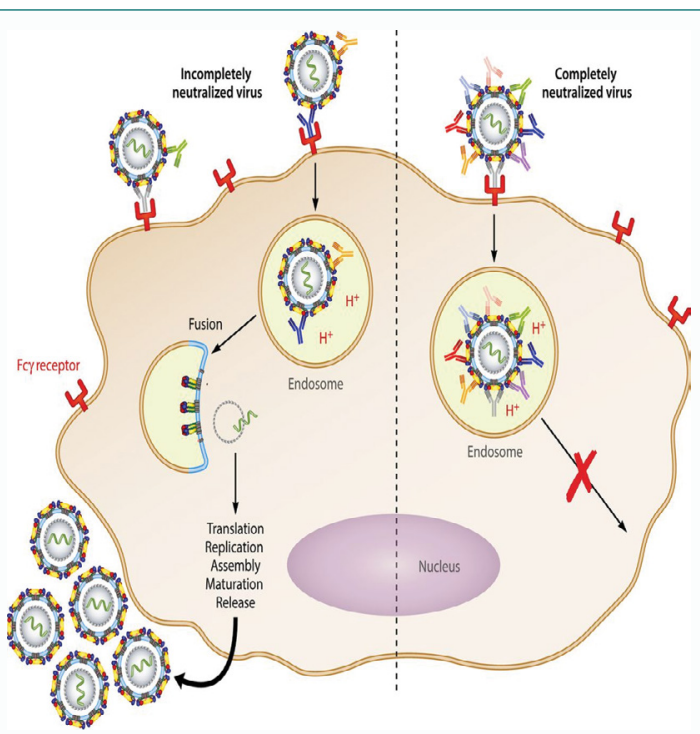

Figure 14: Fc gamma receptors (for IgG or gamma immunoglobulin) facilitate the entry of incompletely neutralized virions.

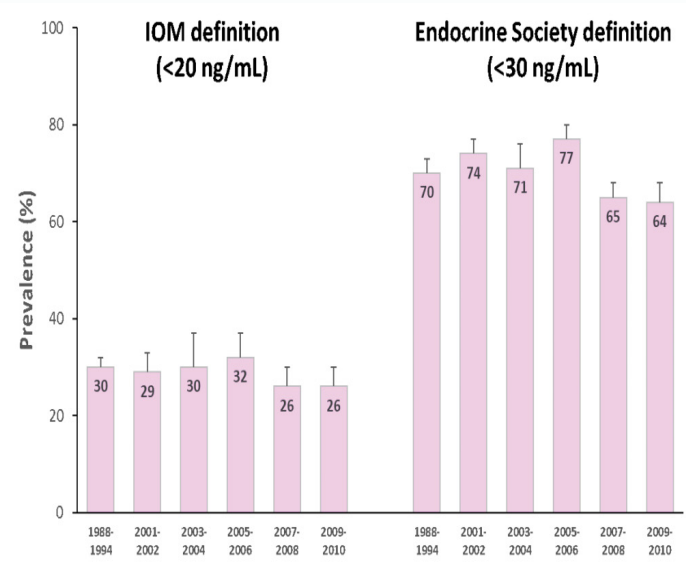

Figure 15: The National Academy of Sciences Institute of Medicine (IOM) determined EAR (Estimated Average Requirement) level of Vitamin D sufficiency of $20 \mathrm{ng} / \mathrm{ml}$ was based on RDA calculations proven to be off by an order of magnitude.

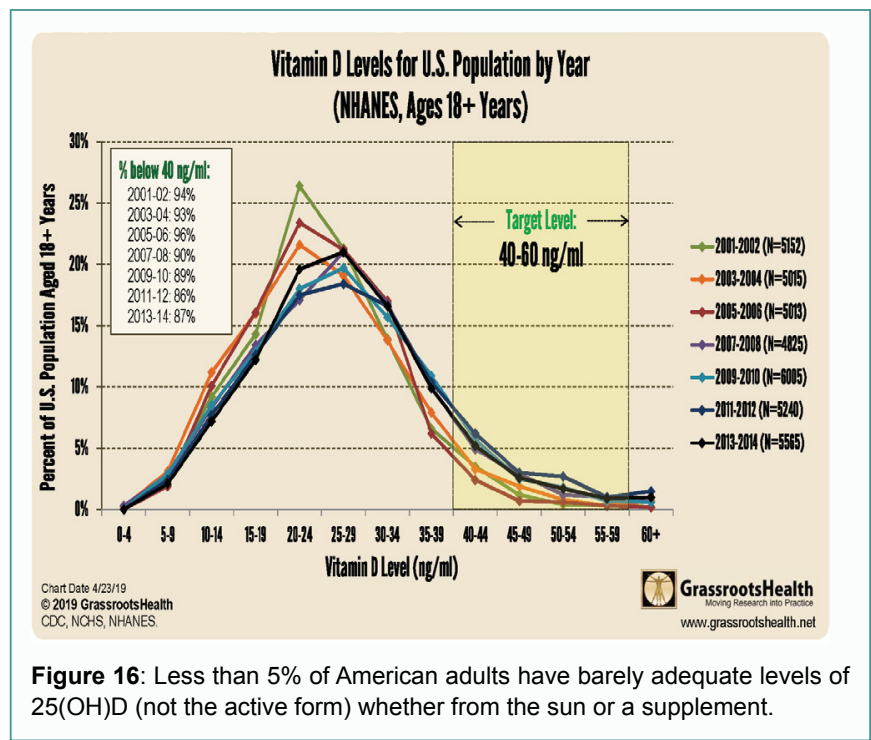

Dr. Fauci reportedly takes 6000 IUs of D3 and some vitamin C (Figure 17,18).

It takes about 2 months to achieve steady state levels of Vitamin D [73] (Figure 19). But sufficient intake or exposure is itself insufficient. In order to produce the active form of vitamin $\mathrm{D}$ magnesium is a required cofactor [74]. Blood magnesium levels are deficient in about $50 \%$ of the population (Figure 20 ).

It's even worse than that. Plasma levels of bound magnesium do not reflect intracellular levels of free unbound magnesium cations, which is the form required to function as a cofactor. Likewise for active vitamin D (Figure 21).

This suggests that over $70 \%$ of the general population is deficient in free magnesium [75]. Therefore any study on the efficacy of vitamin $\mathrm{D}$ with respect to any disease is unreliable, because none of them normalize for magnesium. Any positive benefit reported is vastly understated. Furthermore, articles to date set the threshold for vitamin D sufficiency at greater than $20 \mathrm{ng} / \mathrm{mL}$ or $30 \mathrm{ng} / \mathrm{mL}$. This dilutes the beneficial effects of vitamin $\mathrm{D}$ and uplifts the results for the deficient group. The threshold should be at least $40 \mathrm{ng} / \mathrm{ml}$ and preferably $50 \mathrm{ng} / \mathrm{ml}$ (Figure 22). 


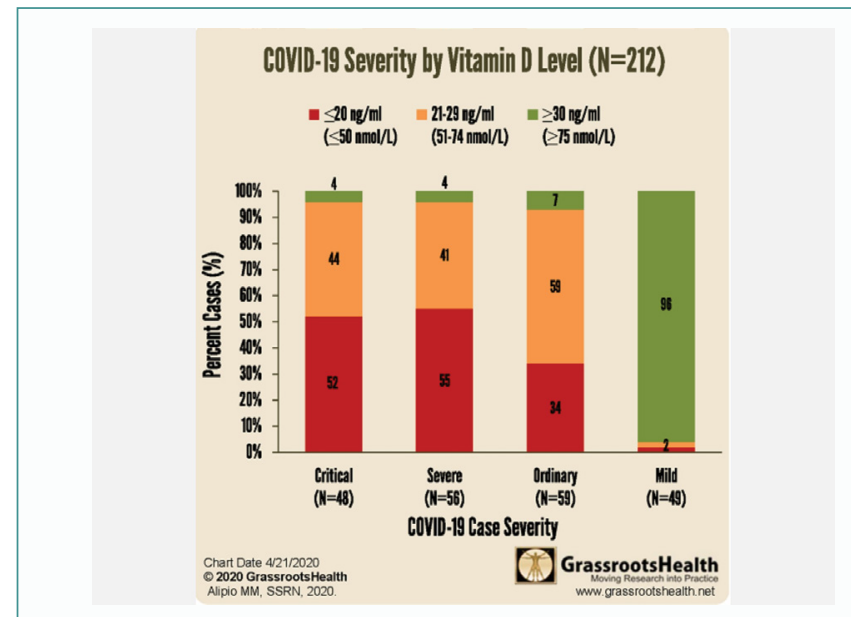

Figure 17: A level of $30 \mathrm{ng} / \mathrm{ml}$ is inadequate to prevent symptomatic disease.

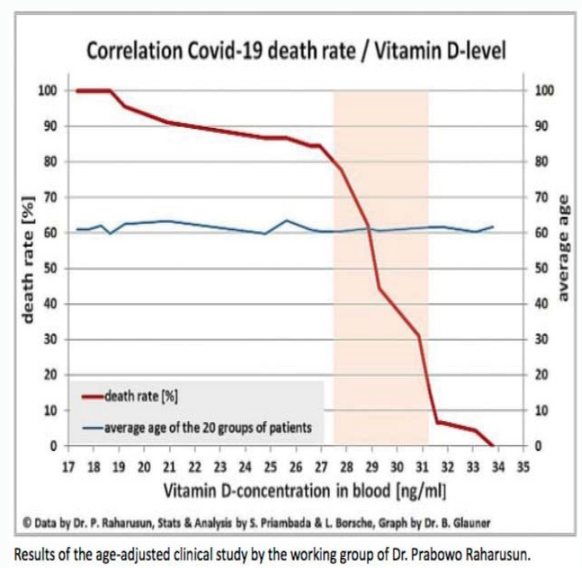

Figure 18: The level of $30 \mathrm{ng} / \mathrm{ml}$ is inadequate to avoid death.

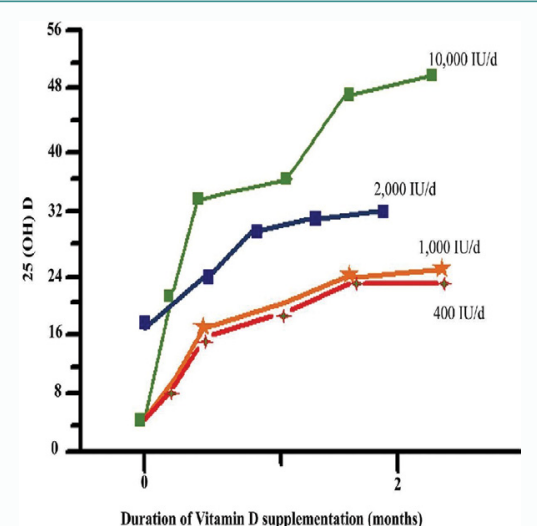

Figure 19: The RDA of 600 IUs to 800 IUs per day is massively inadequate (by an order of magnitude).

\section{Autoimmunity}

CD147 is expressed on erythrocytes, leukocytes, platelets, and endothelial cells. Increased expression of CD147 has been implicated in the pathogenesis of a number of diseases, such as asthmamediated lung inflammation, rheumatoid arthritis, multiple sclerosis, myocardial infarction and ischemic stroke [62].

SARS2 and CD147 could represent a missing link connecting a virus to an autoimmune disease like $\mathrm{KD}$ and others.

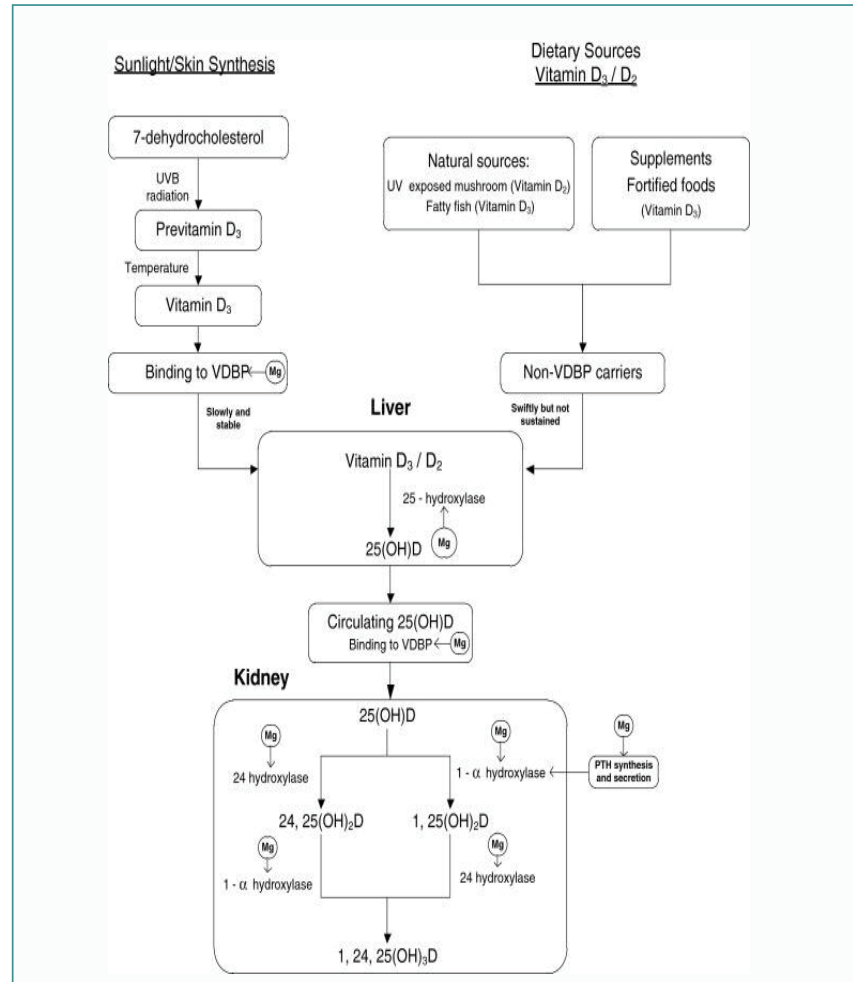

Figure 20: All enzymes necessary for the production of the active form of vitamin $\mathrm{D}$ after sun exposure or supplementation require free magnesium.

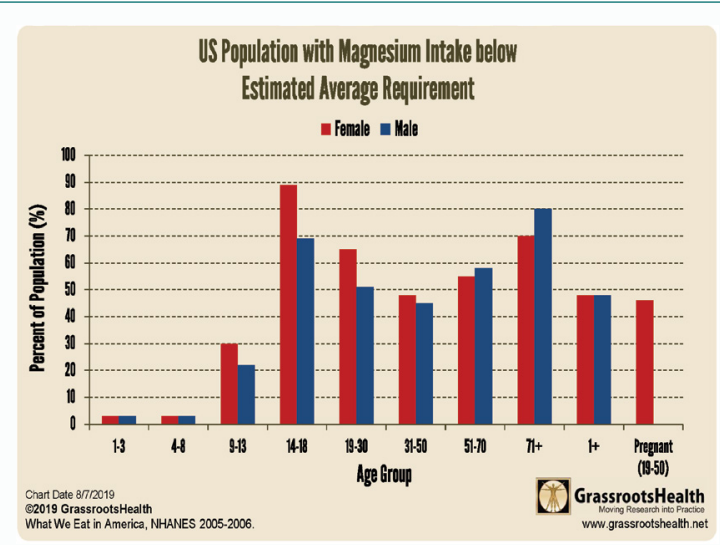

Figure 21: Plasma magnesium levels are deficient in $50 \%$ of the population.

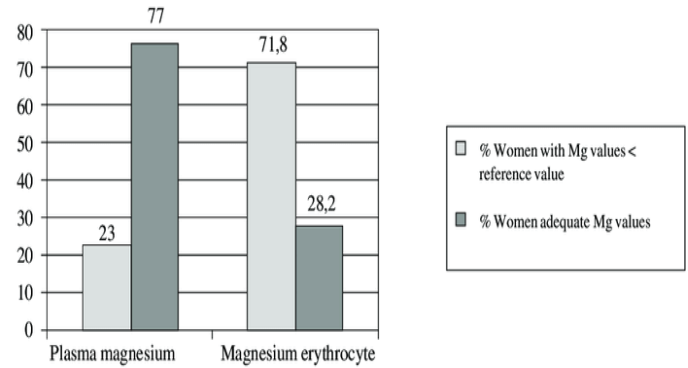

Figure 22: Plasma magnesium levels do not reflect the intracellular free magnesium levels required for the production of active vitamin D. Special tests are necessary to determine this. 


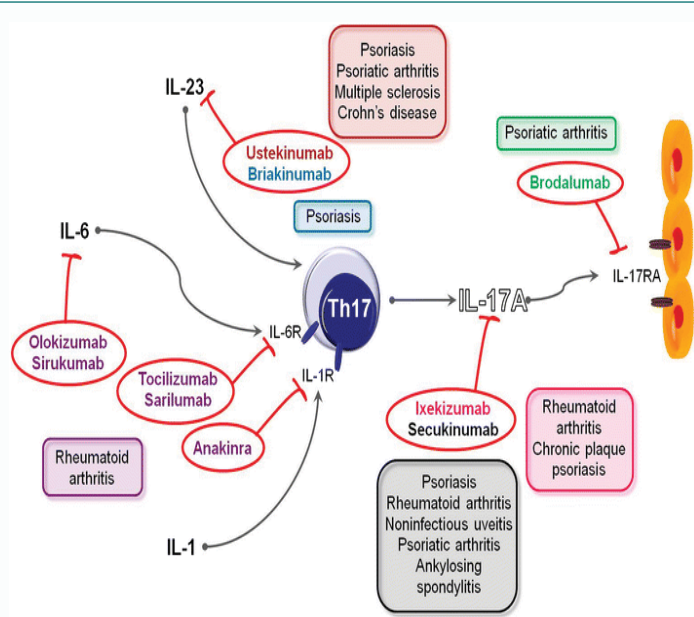

Figure 23: Numerous synthetic antibodies to cytokines associated with numerous autoimmune diseases have been developed by the pharmaceutical industry.

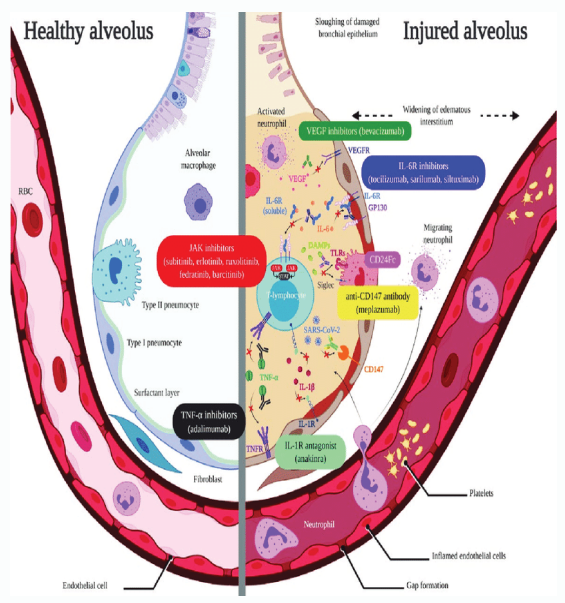

Figure 24: Numerous anti-inflammatory antibodies directed toward specific pro inflammatory cytokines associated with Covid-19 severity have been developed by the pharmaceutical industry.

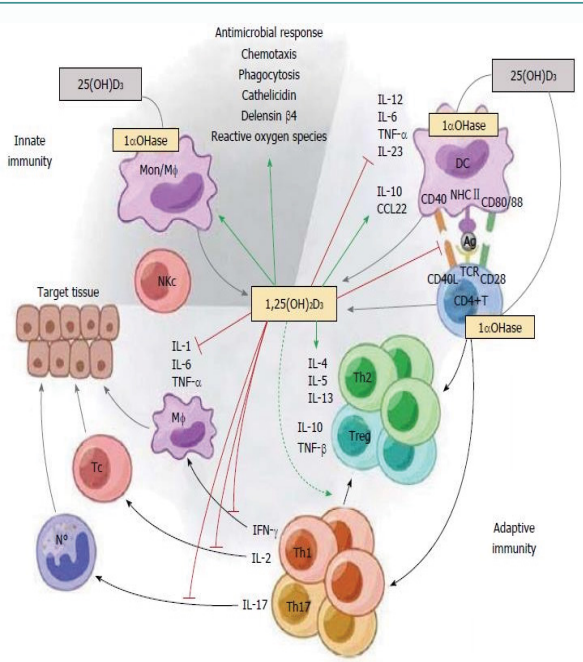

Figure 25: Vitamin $D$ inhibits most of these cytokines associated with either autoimmune disease or Covid-19.

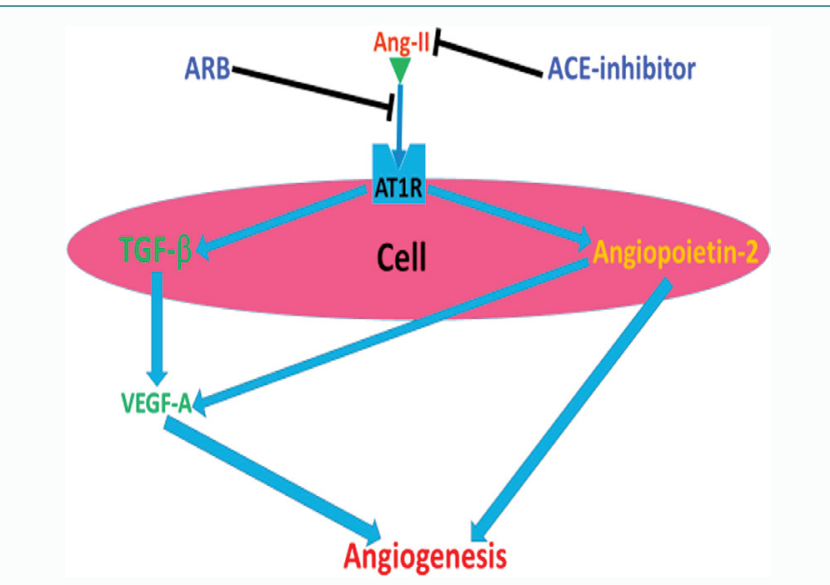

Figure 26: RAS antagonists inhibit Vascular Endothelial Growth Factor (VEGF) aka Vascular Permeability Factor (VPF).

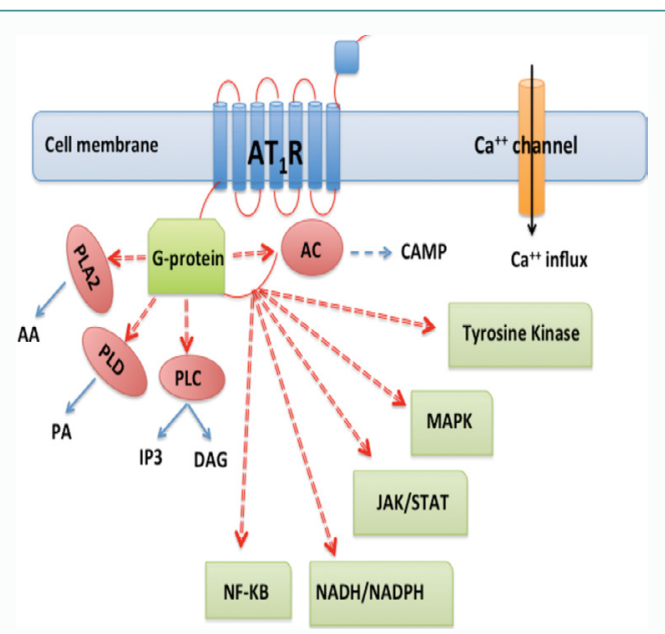

Figure 27: RAS antagonists inhibit other enzymes associated with Covid-19 severity.

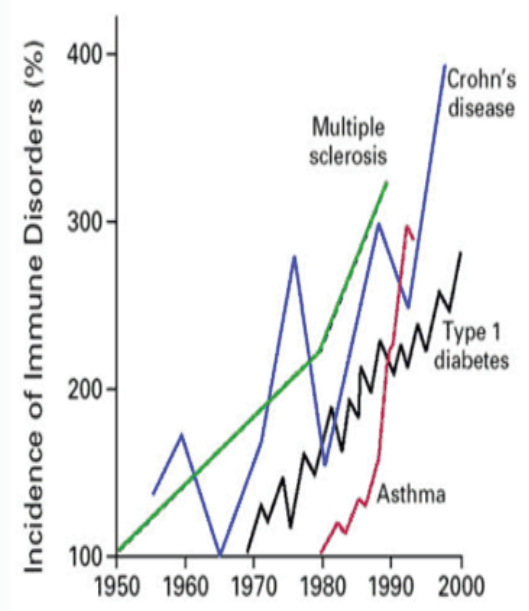

From: Bach JF. The effect of infections on

susceptibility to autoimmune and allergic diseases.

N Engl J Med. Sep 2002;347(12):911-920.

Figure 28: Auto immune diseases are increasing exponentially. 


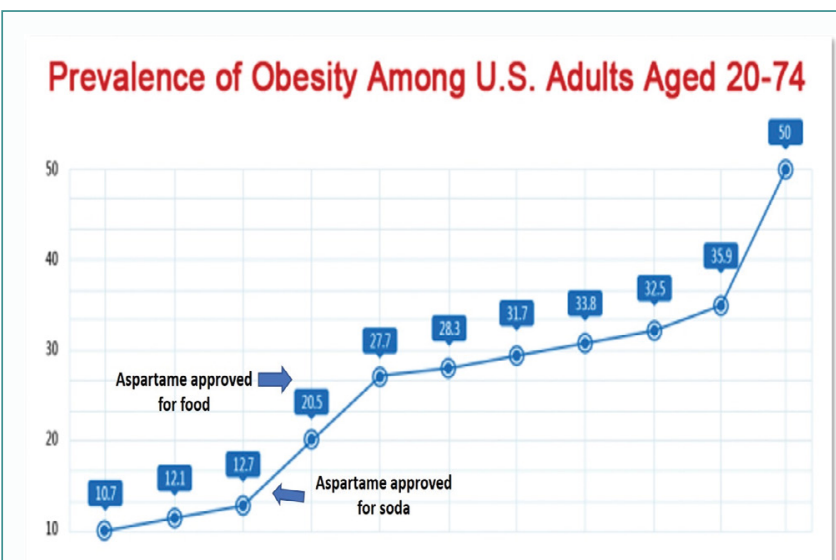

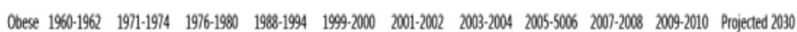

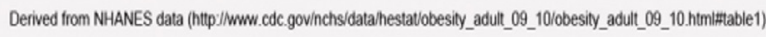

Figure 29: The trend in obesity $(>30 \mathrm{~kg} / \mathrm{m} 2)$ is bad

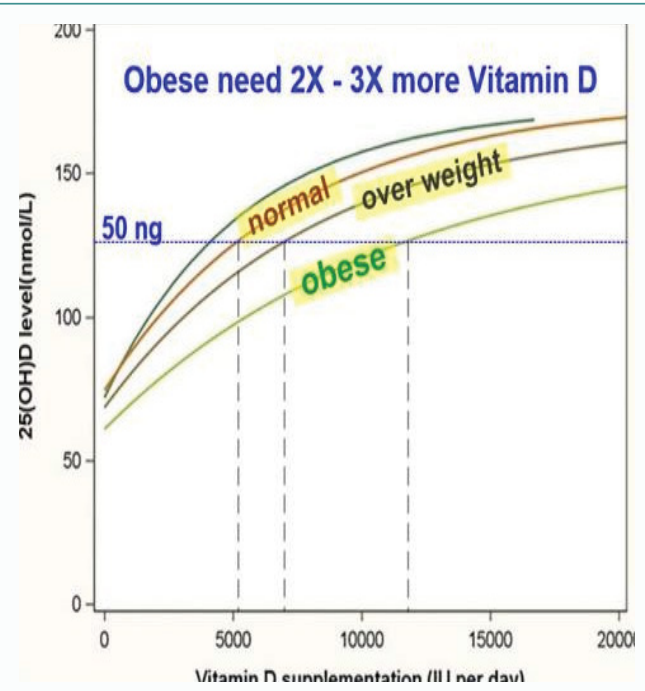

Figure 30: The overweight $(>25 \mathrm{~kg} / \mathrm{m} 2)$ and the obese need significantly more daily vitamin $\mathrm{D}$.

In (figures 23-25) one can see that almost every synthetic antibody to either a cytokine or its receptor that inhibits Covid-19 or some autoimmune disease is a duplicate of what vitamin $\mathrm{D}$ already does [76-78] (Figures 23,24). VEGF and JAK are also inhibited by RAS antagonists $[79,80]$ (Figure 25). Not surprisingly the incidence of autoimmune diseases has paralleled the burgeoning vitamin D deficiency [81] (Figure 26,27). And the increasing prevalence of obesity (Figure 28). The higher the BMI, the higher the recommended dosage of vitamin D [82] (Figure 29,30).

\section{Conclusion}

In view of this ACE2/CD147 hybrid approach to Covid-19 it seems plausible to suggest that the flu like symptoms may be ACE2 mediated and the anosmia/ageusia CD147 mediated.The elevated ACE/ACE2 seen in diabetes and hypertension is further exacerbated bythe destruction of ACE2 receptors. This leads to increased angiotensin II, which supercharges the pro inflammatory arm of the immune response. After entering the adaptiveimmunity phase ARDS may develop in those with comorbidities and/or severe vitamin D deficiency. However, CD147 mediated changes such as TMA and ACovCS may enter the clinical picture, especiallyin the obeseand especially with concomitant vitamin D deficiency. If sufficiently deficient, MIS-C aka PMIS-TSS and MIS-A may present an auto immune component. This analysis of current knowledge on Covid-19 leads to prospective comments about preparation, as Covid-19 is quite contagious. First and foremost everyone should seriously reconsider their vitamin $\mathrm{D}$ and magnesium strategy in general. Knowing your 25(OH)D level is useful. Magnesium status is a more difficult proposition. But symptoms of magnesium deficiency, e.g., leg cramps, constipation, palpitations, are warning signs. Vitamin D deficient ricketswas first diagnosed in the 1920s. It took another 50 years before vitamin D resistant magnesium deficient rickets was recognized in the 1970s. Secondly, ADAM17 triggered by AT1Rs up regulates the pro inflammatory response. The counterbalancing anti inflammatory response is determined by active vitamin D status. Soluble ACE2 and IL-6 reflect poorly on this balance. Possible therapeutic approaches, e.g., RAS antagonist, hydroxychloroquine, melatonin, should be carefully considered. Useful additional easy to obtain clinical information, such as blood type, RDW, d-dimers and platelet count at the outset could prove critical. Randomized, double blind, placebo controlled clinical trials are urgently needed to confirm this interpretation of what we now know about Covid-19.

\section{References}

1. Chen Z, Mi L, Xu J, Yu J, Wang X, Jiang J, et al. Function of HAb18G/CD147 in invasion of host cells by severe acute respiratory syndrome coronavirus. J Infect Dis. 2005;191(5):755-60.

2. Glowacka I, Bertram S, Müller MA, Allen P, Soilleux E, Pfefferle S, et al. Evidence that TMPRSS2 activates the severe acute respiratory syndrome coronavirus spike protein for membrane fusion and reduces viral control by the humoral immune response. J Virol. 2011;85(9):4122-34

3. Wang K, Chen W, Zhou Y, Lian JQ, Zhang Z, Du P, et al. SARS-CoV-2 invades hos cells via a novel route: CD147-spike protein. BIORXIV. 2020

4. Ferrario C, Jessup J, Chappell MC, Averill DB, Brosnihan KB, Tallant EA, et al. Effect of angiotensin-converting enzyme inhibition and angiotensin ii receptor blockers on cardiac angiotensin-converting enzyme 2. Circulation. 2005;111(20):2605-10.

5. Hamming I, Timens W, Bulthuis MLC, Lely AT, Navis GJ, Goor HV. Tissue distribution of ACE2 protein, the functional receptor for SARS coronavirus. A first step in understanding SARS pathogenesis. J Pathol. 2004;203(2):631-7.

6. Ganier C, Du-Harpur X, Harun N, Wan B, Arthurs C, Luscombe NM, et al. CD147 (BSG) but not ACE2 expression is detectable in vascular endothelial cells within single cell RNA sequencing datasets derived from multiple tissues in healthy individuals. BIORXIV. 2020

7. Radzikowska U, Ding M, Tan G, Zhakparov D, Peng Y, Wawrzyniak P, et al Distribution of ACE2, CD147, CD26, and other SARS-CoV-2 associated molecules in tissues and immune cells in health and in asthma, COPD, obesity, hypertension, and COVID-19 risk factors. Allergy. 2020;75(11):2829-45.

8. Dong Y, Mo X, Hu Y, Qi X, Jiang F, Jiang Z, et al. Epidemiology of COVID-19 among children in china. Pediatrics. 2020;145(6):e20200702.

9. Guillon P, Clément M, Sébille V, Rivain JG, Chou CF, Ruvoën-Clouet N, et al Inhibition of the interaction between the SARS-CoV Spike protein and its cellular receptor by anti-histo-blood group antibodies. Glycobiology 2008;18(12):1085-93.

10. Montgomery RR. The heads and the tails of malaria and VWF. Blood 2016;127(9):1081-2.

11. Johansson K, Jansson JH, Johansson L, Ekblom K, Lind MM. Von willebrand factor, $\mathrm{ABO}$ blood group, and risk of first-ever intracerebral hemorrhage: A prospective nested case-control study. Thromb Res. 2020;195:77-80.

12. Wu Y, Feng Z, Li P, Yu Q. Relationship between ABO blood group distribution and clinical characteristics in patients with COVID-19. Clin Chim Acta. 2020;509:220-3. 
13. Yang M, Ng MHL, Li CK. Thrombocytopenia in patients with severe acute respiratory syndrome (review). Hematology. 2005;10(2):101-5.

14. Foy BH, Phil D, Carlson JCT, Reinertsen E, Valls RPI, Lopez RP, et al. Association of red blood cell distribution width with mortality risk in hospitalized adults with SARSCOV-2 infection. JAMA Netw Open. 2020;3(9):e2022058.

15. Coste I, Jean-François Gauchat JF, Wilson A, Izui S, Jeannin P, Delneste Y, et al. Unavailability of CD147 leads to selective erythrocyte trapping in the spleen. Blood. 2001;97(12):3984-8.

16. Balaban DV, Popp A, Lungu AM, Costache RS, Anca IA, Jinga M. Ratio of spleen diameter to red blood cell distribution width. Medicine. 2015;94(15):e726.

17. Arshad S, Kilgore P, Chaudhry ZS, O'Neill W, Zervos M, Wang DD, et al. Treatment with hydroxychloroquine, azithromycin, and combination in patients hospitalized with COVID-19. Int J Infect Dis. 2020;97:396-403.

18. Casian A, Sangle SR, D'Cruz DP. New use for an old treatment: Hydroxychloroquine as a potential treatment for systemic vasculitis. Autoimmun Rev.2018;17(7):660-4.

19. Qiao J, Lia W, Bao J, Peng Q, Wen D, Wang J, et al. The expression of SARS-CoV-2 receptor ACE2 and CD147, and protease TMPRSS2 in human and mouse brain cells and mouse brain tissues. Biochem Biophys Res Commun. 2020;533(4):867-71.

20. Politi LS, Salsano E, Grimaldi M. Magnetic resonance imaging alteration of the brain in a patient with coronavirus disease 2019 (covid-19) and anosmia. JAMA Neurol. 2020;77(8):1028-9.

21. Bougakov D, Podell K, Goldberg E. Multiple Neuroinvasive Pathways in COVID-19. Mol Neurobiol. 2020;1-12.

22. Razakandrainibe R, Pelleau S, Grau GE, Jambou R. Antigen presentation by endothelial cells: what role in the pathophysiology of malaria? Trends in Parasitol. 2012;28(4):151-60.

23. Ball L, Neto AS, Pelosi P. Obesity and survival in critically ill patients with acute respiratory distress syndrome: a paradox within the paradox. Crit Care. 2017;21(1):114.

24. Wyss K, Wångdahl A, Vesterlund M, Hammar U, Dashti S, Naucler P, et al. Obesity and diabetes as risk factors for severe plasmodium falciparum malaria: results from a swedish nationwide study. Clin Inf Dis. 2017;65(6):949-58.

25. He L, Ding Y, Zhang Q, Che X, He Y, Shen H, et al. Expression of elevated levels of proinflammatory cytokines in SARS-CoV-infected ACE2+cells in SARS patients: relation to the acute lung injury and pathogenesis of SARS. J Pathol. 2006;210(3):288-97.

26. Li J, Rong L, Cui R, Feng J, Jin Y, Yu Y, et al. Dynamic changes in serum IL-6, IL-8, and IL-10 are associated with the outcome of patients with severe COVID-19 in ICU. Research Square. 2020.

27. Lyke KE, Burges R, Cissoko Y, Sangare L, Dao M, Diarra I, et al. Serums levels of the proinflammatory cytokines interleukin-1 beta (il-1 $\beta$ ), il-6, il-8, il-10, tumor necrosis factor $\alpha$, and il-12(p70) in malian children with severe plasmodium falciparum malaria and matched uncomplicated malaria or healthy controls. Infect Immun. 2004;72(10):5630-7.

28. Kumar R, Ng S, Engwerda C. The role of il-10 in malaria: a double edged sword. Front Immunol. 2019; 10:229.

29. Casals-Pascual C, Kai O, Newton CRJC, Peshu N, Roberts DJ. Thrombocytopenia in falciparum malaria is associated with high concentrations of IL-10. Am J Trop Med Hyg. 2006;75(3):434-6.

30. Diorio C, Henrickson SE, Vella LA, McNerney KO, Chase J, Burudpakdee C, et al. Multisystem inflammatory syndrome in children and COVID-19 are distinct presentations of SARS-CoV-2. J Clin Invest. 2020;130(11):5967-75.

31. Huang F, Lui X, Sun X, Li Z. IL-10 served as an indicator in severe COVID-19 patients. J Med Virol. 2020.

32. Chen XY, Yan BX, Man XY. TNFa inhibitor may be effective for severe COVID-19: learning from toxic epidermal necrolysis. Ther Adv Respir Dis. 2020; 14:1753466620926800.

33. Morris SB, Schwartz NG, Patel P, Abbo L, Beauchamps L, Balan S, et al. Case series of multisystem inflammatory syndrome in adults associated with sars-cov- 2 infectionUnited Kingdom and United States, march-august 2020. MMWR Morb Mortal Wkly Rep. 2020;69(40);1450-6.

34. Pierrot-Deseilligny C, Souberbielle JC. Contribution of vitamin D insufficiency to the pathogenesis of multiple sclerosis. Ther Adv Neurol Disord. 2013;6(2):81-116.

35. Stagi S, Rigante D, Lepri G, Cerinic MM, Falcini F. Severe vitamin D deficiency in patients with Kawasaki disease: a potential role in the risk to develop heart vascular abnormalities? Clin Rheumatol. 2016;35(7):1865-72.

36. Castillo ME, Costa LME, Barrios JMV, Díaz JFA, Miranda JL, Roger B, et al. Effect of calcifediol treatment and best available therapy versus best available therapy on intensive care unit admission and mortality among patients hospitalized for COVID-19: A pilot randomized clinical study. J Steroid Biochem Mol Biol. 2020;203:105751.

37. Schleicher RL, Sternberg MR, Lacher DA, Sempos CT, Looker AC, Ramon AD, et al. The vitamin D status of the US population from 1988 to 2010 using standardized serum concentrations of 25-hydroxyvitamin D shows recent modest increases. American J Clin Nutrition. 2016;104(2):454-61.

38. Stringer E, Yeung RSM. Pathogenesis of Kawasaki disease: The central role of TNFa. Future Rheumatol. 2008;3(1):69-77.

39. Cruz-Olivoa F, García-Elorriaga G, González-Bonilla C, Rey-Pinedacd G, MancillaRamíreze J. Tumor necrosis factor -308 and lymphotoxin +252 polymorphisms in Mexican children with Kawasaki disease and coronary aneurysms. Arch Med Res. 2011;42(7):602-7.

40. Fast DJ, Schlievert PM, Nelson RO. Toxic shock syndrome-associated staphylococcal and streptococcal pyrogenic toxins are potent inducers of tumor necrosis factor production. Infect Immun.1989;57(1):291-4.

41. Dolinger MT, Person H, Smith R, Jarchin L, Pittman N, Marla CD, et al. Pediatric Crohn Disease and Multisystem Inflammatory Syndrome in Children (MIS-C) and COVID-19 Treated With Infliximab. J Pediatr Gastroenterol Nutr. 2020;71(2):153-5.

42. Leão L, Puty B, Dolabela MF, Povoa MM, Yago GD, Eiro LC, et al. Association of cerebral malaria and TNF- $\alpha$ levels: a systematic review. BMC Infect Dis. 2020;20:442.

43. Offringa A, Montijn R, Singh S, Paul M, Pinto YM, Pinto-Sietsma SJ, The mechanistic overview of SARS-CoV-2 using angiotensin-converting enzyme 2 to enter the cell for replication: possible treatment options related to the renin-angiotensin system. Eur Heart J Cardiovasc Pharmacother. 2020;6(5):317-25.

44. Chhabra KH, Harshita C, Eric L. Angiotensin converting enzyme 2: a new important player in the regulation of glycemia. IUBMB Life. 2013;65(9):731-8.

45. Kornilov SA, Lucas I, Jade K, Dai CL, Lovejoy JC, Magis AT, et al. Plasma levels of soluble ACE2 are associated with sex, Metabolic Syndrome, and its biomarkers in a large cohort, pointing to a possible mechanism for increased severity in COVID-19. Crit Care. 2020;24:452.

46. John SR. IL-6 trans-signaling via the soluble il-6 receptor: importance for the proinflammatory activities of il-6. Int J Biol Sci. 2012; 8(9):1237-47.

47. Gabay C. Interleukin-6 and chronic inflammation. Arthritis Res Ther. 2006;8:S3

48. Nakayama Y, Ueda S, Okuma S. Molecular mechanism underlying the renoprotective action of vitamin D. Circ J. 2014;78(3):599-600.

49. Park MH, Hong JT. Roles of NF- $\mathrm{BB}$ in cancer and inflammatory diseases and their therapeutic approaches. Cells. 2016;5(2):15.

50. Chu H, Chan JFW, Wang Y, Yuen TTT, Chai Y, Hou Y, et al. Comparative replication and immune activation profiles of sars-cov-2 and sars-cov in human lungs: an ex vivo study with implications for the pathogenesis of covid-19. Clin Infect Dis. 2020;71(6):1400-9.

51. Yuen CK, Lam JY, Wong WM, Mak LF, Wang X, Chu H, et al. SARS-CoV-2 nsp13, nsp14, nsp15 and orf6 function as potent interferon antagonists. Emerg Microbes Infect. 2020;9(1):1418-28.

52. Liu Y, Yang Y, Zhang C, Huang F, Wang F, Yuan J, et al. Clinical and biochemical indexes from 2019-nCoV infected patients linked to viral loads and lung injury. Sci China Life Sci. 2020;63(3):364-74. 
53. Hoepel W, Chen HJ, Allahverdiyeva S, Manz X, Aman J, Amsterdam UMC, et al Anti-SARS-CoV-2 IgG from severely ill COVID-19 patients promotes macrophage hyper-inflammatory responses. Biorxiv. 2020.

54. Danquah I, Bedu-Addo G, Mockenhaup FP. Type 2 diabetes mellitus and increased risk for malaria infection. emerging infectious diseases. Emerg Infect Dis. 2010;16(10):1601-4.

55. Wyss K, Wångdahl A, Vesterlund M, Hammar U, Dashti S, Naucler P, et al. Obesity and diabetes as risk factors for severe plasmodium falciparum malaria: results from a swedish nationwide study. Clin Infect Dis. 2017;65(6):949-58.

56. Al-Benna S. Association of high level gene expression of ACE2 in adipose tissue with mortality of COVID-19 infection in obese patients. Obes Med. 2020;100283.

57. Sehirli AO, Sayiner S, Serakinci N. Role of melatonin in the treatment of COVID-19; as an adjuvant through cluster differentiation 147 (CD147). Mol Biol Rep. 2020;47(10):8229-33

58. Vasquez GF, Reiter RJ, Agil A. Melatonin increases brown adipose tissue mass and function in Zücker diabetic fatty rats: implications for obesity control. J Pineal Res. 2018;64(4): e12472.

59. Favero G, Stacchiotti A, Castrezzati S, Bonomini F, Albanese M, Rezzani R, et al Melatonin reduces obesity and restores adipokine patterns and metabolism in obese (ob/ob) mice. Nutr Res. 2015;35(10):891-900.

60. Qiao J, Li W, Bao J, Peng Q, Wen D, Wang J, et al. The expression of SARS-CoV-2 receptor ACE2 and CD147, and protease TMPRSS2 in human and mouse brain cells and mouse brain tissues. Biochem Biophys Res Commun. 2020;533(4):867-71.

61. Biesalski HK. Vitamin D deficiency and co-morbidities in COVID-19 patients- A fatal relationship? NFS J. 2020;20:10-21.

62. Zhu X, Song Z, Zhang S, Nanda A, Li G. CD147: A novel modulator of inflammatory and immune disorders. Current Medicinal Chem. 2014;21(19):2138-45.

63. Health department-reported cases of multisystem inflammatory syndrome in children (mis-c) in the United States. CDC. 2020.

64. Yoon HE, Kim EN, Kim MY, Lim JH, Jang IA, Ban TH, et al. Age-associated changes in the vascular renin-angiotensin system in mice. Oxidative Med Cellular Longevity. 2016.

65. Bunyavanich S, Do A, VicencioA. Nasal gene expression of angiotensin-converting enzyme 2 in children and adults. JAMA. 2020;323(23):2427-9.

66. Choe P, Kang C, Suh H, Jung J, Kang E, Lee SY, et al. Antibody responses to sarscov-2 at 8 weeks postinfection in asymptomatic patients. Emerg Infect Dis. 2020;26(10):2484-7.

67. Katzelnick LC, GreshL, HalloranME, Mercado JC, Kuan G, Gordon A, et al. Antibody-dependent enhancement of severe dengue disease in humans. Science. 2017;358(6365):929-32.

68. Heinz FX, Stiasny K. The antigenic structure of zika virus and its relation to other flaviviruses: implications for infection and immunoprophylaxis. Microbiol Mol Biol Rev. 2017;81(1):e00055-16.
69. Schleicher RL, Sternberg MR, Lacher DA, Sempos CT, Looker AC, Durazo-Arvizu RA, et al. The vitamin D status of the US population from 1988 to 2010 using standardized serum concentrations of 25 -hydroxyvitamin D shows recent modest increases. American J Clin Nutri. 2016;104(2):454-61.

70. Veugelers PJ, Ekwaru JP. A statistical error in the estimation of the recommended dietary allowance for vitamin D. Nutrients. 2014;6(10):4472-5

71. Pilz S, Dobnig H, Nijpels G, Heine RJ, Stehouwer CDA, Snijder MB, et al. Vitamin D and mortality in older men and women. Clin Endocrinol. 2009;71(5):666-72.

72. Raharusuna P, Priambada S, Budiarti C, Agung E, Budi C. Patterns of covid-19 mortality and vitamin d: an indonesian study. 2020

73. John HL, James HO, David B, Donald DH, Michael FH. Vitamin D deficiency: an important, common, and easily treatable cardiovascular risk factor? J American College Cardiol. 2008;52(24):1949-56.

74. Deng X, Song Y, Manson JE, Signorello LB, Zhang SM, Shrubsole MJ, et al. Magnesium, vitamin D status and mortality: results from us national health and nutrition examination survey (nhanes) 2001 to 2006 and nhanes iii. BMC Med. 2013;11:187.

75. López GB, Molina LJ, Florea DI, Quintero OB, Antonio PC, Elena MP. Association between magnesium-deficient status and anthropometric and clinical-nutritional parameters in posmenopausal women. Nutr Hosp. 2014;29(3):658-64.

76. Tabarkiewicz J, Pogoda K, Karczmarczyk A, Piotr P, Giannopoulos K. The role of il-17 and th17 lymphocytes in autoimmune diseases. Arch Immunol Ther Exp (Warsz). 2015;63(6):435-49.

77. Chastain DB, Stitt TM, Ly PT, Henao MAF, Paredes CF, Osae SP. Countermeasures to COVID-19: Are immunomodulators rational treatment options - a critical review of the evidence. Open Forum Infect Dis. 2020;7(7):ofaa219.

78. Saberi B, Dadabhai AS, Nanavati J, Wang L, Shinohara RT, Mullin GE. Vitamin D levels do not predict the stage of hepatic fibrosis in patients with non-alcoholic fatty liver disease: A PRISMA compliant systematic review and meta-analysis of pooled data. World J Hepatol. 2018;10(1):142-54.

79. Houston BA, Schneider ALC, Vaishnav J, Cromwell DM, Miller PE, Faridi KF Angiotensin II antagonism is associated with reduced risk for gastrointestinal bleeding caused by arteriovenous malformations in patients with left ventricular assist devices, J Heart Lung Transplantation. 2017;36(4):380-5

80. Ismail B. Angiotensin ii type 1 receptor (at1r) changes in animal model of chronic kidney disease: evaluation and pharmacotherapy. Thesis Univ Ottaw. 2016.

81. Bach JF. The effect of infections on susceptibility to auto immune and allergic diseases N Engl J Med. 2002;347(12):911-20.

82. Ekwaru JP, Zwicker JD, Holick MF, Giovannucci E, Veugelers PJ. The importance of body weight for the dose response relationship of oral vitamin D supplementation and serum 25-hydroxyvitamin D in healthy volunteers. PLoS One. 2014;9(11):e111265. 